\title{
山口県道路施設維持管理のための リアルタイム観測・予測システム構築と実証
}

\author{
山根 智1・吉村 崇2 ・宮本文穂3 \\ 1正会員 山口県土木建築部砂防課（†753-8501 山口県山口市滝町1番1号） \\ E-mail:yamane.satoru@pref.yamaguchi.lg.jp \\ 2 山口県土木建築部道路整備課（†753-8501 山口県山口市滝町1番1号） \\ E-mail: yoshimura.takashi@pref.yamaguchi.lg.jp \\ 3フェロー会員 山口大学大学院教授（干755-8611山口県宇部市常盤台二丁目16-1） \\ E-mail: miya818@yamaguchi-u.ac.jp
}

\begin{abstract}
安全で安心な社会基盤の要（かなめ）となる道路関連施設の維持管理に情報通信技術（ICT）を積極的 に取り入れ，リアルタイムで観測および予測を行うシステムの構築と実際への適用例を具体的に述べる. すなわち，道路関連施設の維持管理において，近年著しい普及をみせているGPS機能付きカメラ携帯電話 端末機（以降GPS携帯電話）とWeb-GISに着目し，必要な情報にGPS携帯電話から取得した位置情報を付 加し, 道路管理事務所へ送信することにより, Web-GIS上で位置と情報（画像含む）がリアルタイムに把 握できる道路施設維持管理支援システムの開発と本格導入に向けての操作性向上などのシステム改良を系 統的に紹介するものである.
\end{abstract}

Key Words : Road facility, Maintenance, Real-time, Forecasting, Support system, GPS mobile phone

\section{1. はじめに}

道路関連施設は，道路利用者の生活に密着した最も身 近な社会基盤施設であり，これらに対する維持管理の要 望，苦情など住民からのニーズが多様化している傾向に ある.このような状況下，住民の安全・安心な生活を守 るためには，今後も道路関連施設を適切に維持管理する ことが重要であり，より効率的かつ効果的に道路関連施 設を維持管理する仕組みが必要である．また，山口県は 中国山脈によって山陽側と山陰側に分断され，気象特性 などに大きな地域差が見られる上に，平地がそしく地形 が錯綜して急傾斜地が多く存在するため，近年において は豪雨時に甚大な災害が発生し，道路網が寸断されるこ とも多く，災害時における迅速な対応が重要となってい る1). そして，県北部では冬期の積雪や路面凍結などに よるスリップ事故，それに伴う道路施設損傷や渋滞など を引き起こしているため, 的確な除雪作業, 塩力ル散布 などの冬期対応が望まれている.

このように山口県における維持管理業務は，施設に関 する通常の維持管理に加えて, 道路利用者からの要望・ 苦情などの対応，また事業執行に対寸る説明責任，関係 機関との協議・調整さらには，緊急対応を要する災害な
ど業務内容が多岐にわたっており, 職員の業務負担は過 多となってきている2,3). そのため, 各所の出先事務所

（土木建築事務所）での的確な維持管理を遂行するため には業務の効率化，さらには情報の共有化を図ることに よって業務負担の増加を可能な限り軽減することが必要 となる.

上記のような業務負担増を改善するため, 各所の土木 建築事務所では，従来の紙ベースの書類による事務処理 に代えて, 汎用ソフト（Excel／Access など）を一部導 入し，またデジタル化した道路台帳とも組み合わせた支 援システムの構築によって業務負担増の改善を試みてき た。しかしながら，道路施設損傷の発生位置を把握する のに管内図や道路台帳および市販（例えば，ゼンリン社 製）の地図，さらには当該住所などから具体的な案件発 生場所を特定する作業に手間が掛かる，そして，維持管 理委託業者への作業指示などについても，FAX 等でのや りとりに時間を要してしまう状況にある。また，災害時 では初期対応を迅速・的確に実施することが早期の復旧 に繋がり，そのためには早期の状況把握および情報共有 が不可欠である．冬期では，路面状況などをリアルタイ ムに情報提供することにより，除雪ルートを的確に判 断・指示することができ，効率的な除雪が行われ，それ 
に伴う事故発生の抑制，さらには通行止めによる迂回路 の検討など効果的な対応が必要である.

以上の背景から, 本研究では, 道路施設の損傷発生現 場などの位置情報と問題案件の画像がリアルタイムに把 握できるなどの業務の効率化や災害直後等における関係 機関一の報告と委託業者に対寸る指示が迅速に行える伝 達・対応の迅速性の向上を図る，そして，問題案件の処 理状況および進渉状況が，いつでも，どこでも，だれで も確認できるなどの情報の共有化を図る.これらを目的 として，GPS 携带電話と Web-GIS を活用し，道路施設維 持管理支援システムの開発を行い，その実用化および導 入効果に関して具体的に述べる.

\section{2. 従来の研究と本研究の位置付け}

日本で移動可能な電話機が初めて実用化されたのは, 1979 年の自動車電話である. その後, 小型化, 軽量化 されて行き，1987 年に NTT が日本で初めて携帯電話少 ービスを開始した. 2000 年代に入り, カメラが内蔵さ れるなど携帯電話の機能は向上の一途を辿ってきており, また，GPS 機能は 2007 年 4 月総務省において事業用電 気通信設備規則が施行され，その後に発売される $3 G$ 携 帯電話端末機以降は，原則として GPS モジュールの内 蔵が義務付けられ，誰もがその存在を認知している機能 となっている. 現在, GPS 携帯電話の位置情報を利用し た地図サービスやナビゲーション(道案内)サービス，地
域情報提供サービス，子どもの居場所を親が把握できる サービスなどが提供されている．また，事故を起こした 場合に，位置情報を自動的に送信する緊急通報サービス や，消防や警察への通報時に自動的に位置情報を送信す るといったものもある.この GPS 携帯電話の位置情報 機能と Web-GIS を組み合わせた道路施設維持管理支援 システムの開発を行った。これは道路施設の損傷，災害 時などインターネットを介し, 道路管理者がパソコンで 現状を正確に把握でき，そのデータを基に迅速な対応が 可能となる．簡単に言えば，GPS 携帯電話の位置情報機 能および写真機能とメール機能を最大限利用し，現場で 発生した道路施設損傷や災害の状況，それに対する対応 策などをパソコンと GPS 携帯電話とのやりとりで瞬時 に情報共有を図ることができるものである．既に，これ らに関連するシステム開発 ${ }^{4,5,6,6), 7)}$ が行われており, 道 路維持管理業務はもちろん，災害時など緊急を要寸場合 でも迅速に対応できるよう行政機関と委託業者とこれま で以上の連携が図られ効果的な維持管理が行われている。 山口県においても，前述したとおり業務の軽減および 効率化，さらに災害時における迅速な対応を図るため, 道路施設維持管理業務の現状と課題を整理・分析し，既 往研究を踏まえ, より効果的な機能(表-1)を付加し道路 施設維持管理支援システムの開発を行った。そして，開 発にあたり GPS 携帯電話を活用した情報提供にはいくつ かの課題があることから，それらを解消する手法につい て, 次の 3 項目について検証を行った :

(1)GPS 携帯電話で取得する位置情報と実際撮影した場所

表-1 主なシステム機能の概要と効果

\begin{tabular}{|c|c|c|}
\hline システム機能 & 概要 & 効果 \\
\hline 情報区分 & 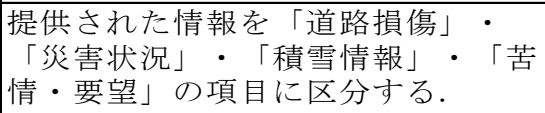 & $\begin{array}{l}\text { 多くの区分を設けることなく, 情報が } \\
\text { 整理されるため容易に状況が把握でき } \\
\text { る. }\end{array}$ \\
\hline 位置修正 & $\begin{array}{l}\text { 情報提供された位置が現場条件等に } \\
\text { よって, 異なる位置を示す場合があ } \\
\text { るため, その位置修正を行うことが } \\
\text { できる. }\end{array}$ & $\begin{array}{l}\text { 位置を示したフラッグをつかみ移動さ } \\
\text { せるだけで簡単に修正が可能となる. } \\
\text { もちろん, 座標を入力することでも修 } \\
\text { 正可能である. }\end{array}$ \\
\hline $\begin{array}{l}\text { 複数枚登録機 } \\
\text { 能と写真回転 } \\
\text { 修正 }\end{array}$ & $\begin{array}{l}\text { 情報提供された画像の複数枚の表示 } \\
\text { を可能とし,ささら画像を } 360^{\circ} \\
\text { 回転させることができる. }\end{array}$ & $\begin{array}{l}\text { 複数枚の画像を添付し送信しても, シ } \\
\text { ステムが対応しているで, 現場での } \\
\text { 情報提供する作業の手間が省ける. } \\
\text { た, 携帯電話で撮影した場合, 機種に } \\
\text { よって, 縦や横撮影にばらつきがある } \\
\text { ため, 写真を回転して修正することが } \\
\text { できる. }\end{array}$ \\
\hline 検索機能 & $\begin{array}{l}\text { 蓄積されたデータを案件ごとに検索 } \\
\text { するこができ、案件の状況を素早 } \\
\text { く簡単に表示させることができる. }\end{array}$ & $\begin{array}{l}\text { 担当者以外が案件を取り扱う場合でも } \\
\text { 検索機能を用いれば, 簡単に情報の処 } \\
\text { 理状況が把握できるため, 迅速かつ適 } \\
\text { 切な対応が可能となる. }\end{array}$ \\
\hline $\begin{array}{l}\text { 報告書の作成 } \\
\text { およ゙印刷 }\end{array}$ & $\begin{array}{l}\text { 情報提供されたものから自動時に報 } \\
\text { 告書が作成され、かつ印刷も簡単に } \\
\text { 行える. }\end{array}$ & $\begin{array}{l}\text { それぞれの情報をデータベース化して } \\
\text { いるので，報告書の作成が自動的に行 } \\
\text { われ，かつ印刷もできる. }\end{array}$ \\
\hline
\end{tabular}


と異なる場合があるため，その位置情報がどの程度ずれ るのか精度の確認を行い, 位置情報の修正機能を付加し た.

(2)GPS 携帯電話で道路施設損傷を撮影し情報提供するこ ととなるが，この場合にどの程度の写真解像度が必要で あるのか道路施設維持管理における必要な有効画素数に ついて検証した.

(3)携帯電話に特有の通信できない地域いわゆる圈外での 情報提供の手法について，簡単で安価にできることを主 眼とする QR コードを用いた座標の取得方法の一例を示 した.

以上，GPS 携帯電話を活用した情報提供について，課 題と本研究の取り組みを表-2に取りまとめた.

また，本システムで蓄積された有用なデータを活用し， 維持管理におけるハード対策や維持管理パトロールの効 率化を可能とする手法について検討した．既往研究では, 道路維持管理システムの長期運用によるデータの整理と 分析 ${ }^{8)}$ やデータマイニングを用いた維持管理における 予防保全的なデータとして活用 ${ }^{9)}$ などの研究がなされ ているが具体的な実用例がない，そこで，本研究では 2 つの具体的な事例を示し活用手法について提案した。

\section{3. 現状と課題}

\section{（1） 道路施設維持管理における現状と課題}

山口県内の現在の土木建築事務所における道路施設維 持管理業務をいくつかのプロセスに分類して，業務フロ 一を明確（ステップ）化し，それぞれのステップにおけ る課題を抽出したものが図-1である。

表-2ＧPS 携帯電話を活用した情報提供の課題

\begin{tabular}{|c|c|c|}
\hline & 課題 & 課題に対する本研究の取組 \\
\hline (1) & $\begin{array}{l}\text { 位置情報を取得する際に, } \\
\text { 補足する衛星の数が少ない } \\
\text { 場合には位置の精度が悪い. }\end{array}$ & $\begin{array}{l}\text { 3キャリアの携带電話を用 } \\
\text { いて, 市街地や山間部など } \\
\text { で位置情報を取得し, ごの } \\
\text { 程度誤差が生じるのか把握 } \\
\text { し, 位置修正機能の設計に } \\
\text { 反映させる. }\end{array}$ \\
\hline (2) & $\begin{array}{l}\text { 携帯電話によって, 画素数 } \\
\text { の上限が異なるため, 場合 } \\
\text { によっては、損傷を確認で } \\
\text { きるまでの画像が提供されれ } \\
\text { ない場合もある. 逆に画素 } \\
\text { 数が多い場合はデータ量も } \\
\text { 多くなるため, 通信費が高 } \\
\text { くなる. }\end{array}$ & $\begin{array}{l}\text { 維持管理に必要な有効画素 } \\
\text { 数について, 視覚とコスト } \\
\text { の両面を検証し, 最適な情 } \\
\text { 報提供を確認する. }\end{array}$ \\
\hline (3) & $\begin{array}{l}\text { 通信不能区間（圈外）で } \\
\text { は、情報提供および位置情 } \\
\text { 報が取得できない. }\end{array}$ & $\begin{array}{l}\text { 圈外における情報提供につ } \\
\text { いて，QRコードを活用し位 } \\
\text { 置情報を取得する手法を考 } \\
\text { 案する. }\end{array}$ \\
\hline
\end{tabular}

主要課題として挙げられるのは，(1)報告を受けた職員が 位置を把握するのに時間を要する，(2)管内図，道路台帳 などのコピーや画像印刷，報告書作成および委託業者へ の依頼など様々な作業が一元化されておらず非効率であ る，(3災害などの各種案件に対して情報の共有化が図ら れていない，(4)紙での整理であるため，過去の案件を検 索するのに時間を要し，収納スペースの確保も必要とな る,などである（図-1右側参照）。

\section{（2） 事務所統廃合による災害時対応の懸念}

過去，山口県は 14 土木建築事務所で道路維持管理や 災害時対応を行っていたが，行政組織改革により，広域 生活圏ごとに 1 事務所を基本とする 8 つ土木建築事務 所に再編された（図-2参照）。
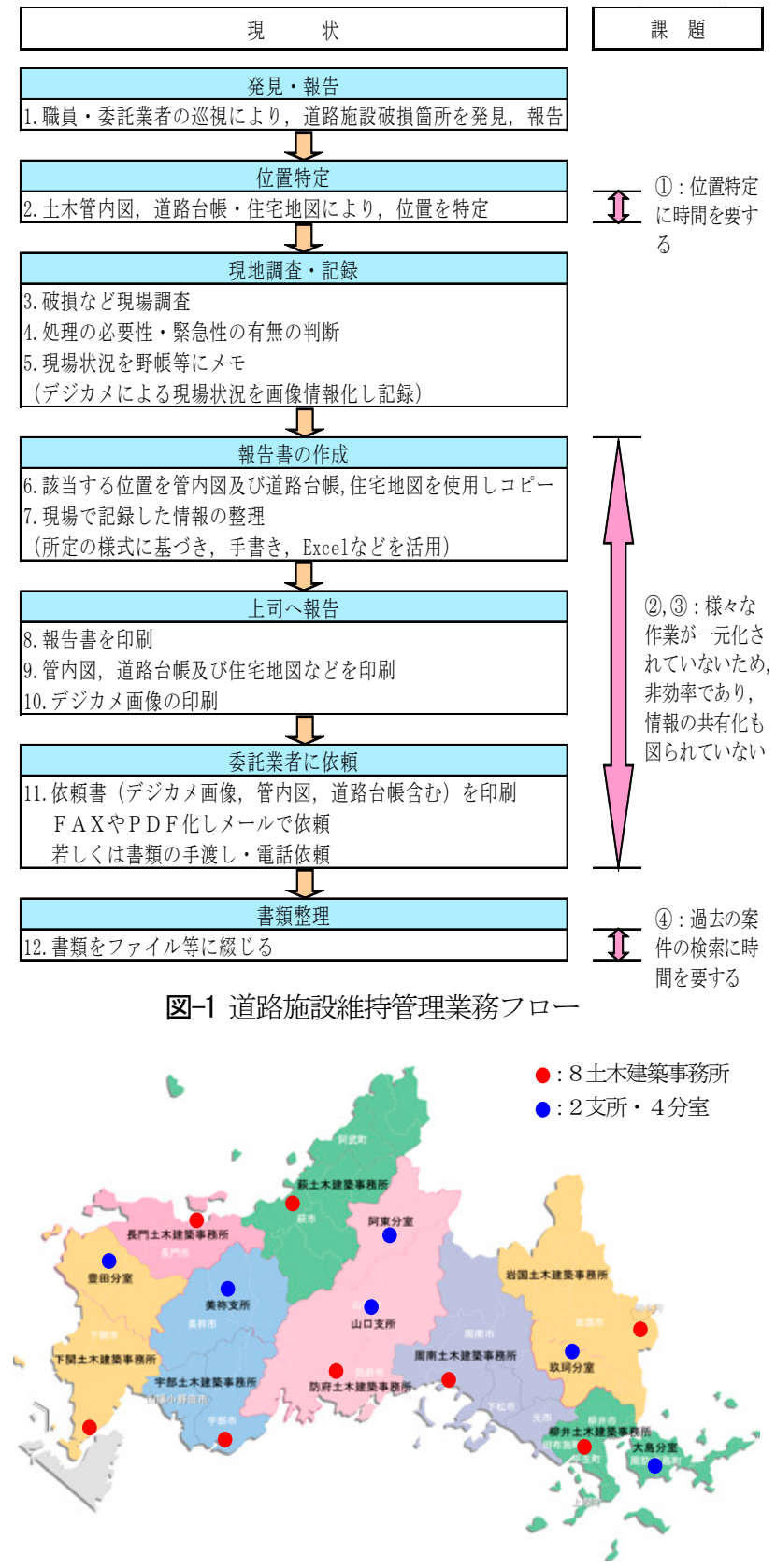

図-2 土木建築事務所配置図(平成 23 年 10 月現在) 
通常の道路維持管理業務は，支所および分室として存 続させ，県民サービスが低下することなく維持管理が行 われ，また，災害発生の場合においても土木建築事務所 との連携を図りながら対応を行っている. しかしながら, 同時多発的な災害が発生した場合，災害情報が土木建築 事務所，支所または分室で錯綜することが懸念される. また，道路災害などにより通行止めとなった場合，事務 所に戻りたくても戻れない状況も想定され，詳細な状況 報告が遅れる可能性も考えられる.

\section{4. 道路施設維持管理支援システムの開発}

\section{(1) 本システムの流れと構成}

Web-GISは, GIS の機能をインターネット上で実現し, 誰もが，いつでも，どこからでも地域情報を入力できる， あるいは閲覧できるようにしたものである.これと位置 情報を提供する GPS 携帯電話との連携を図ることによ り, ユーザ（道路管理者）へ位置と画像をリアルタイム に提供することができる．本システムでは基盤地図とし て，米 Google 社が提供している Google マップ 10) を
Web-GIS として利用しシステム構築を行った. システム の流れは，図-3 に示すように道路施設損傷を発見した 際，GPS 携帯電話で撮影し，これを所定のサーバへ送信 することにより，道路管理者が Web-GIS 上で位置情報 と損傷状況がリアルタイムに把握でき，迅速な対応と情 報の共有化が図られ，効率的・効果的な維持管理を行う ことができる，そして，システム構成は，情報共有の効 率化やシステム利用の常用性を図るため, 道路損傷・災 害状況・積雪状況・苦情要望の 4 つの項目に分類・整理 できることとした．平時は道路施設, 積雪状況, 苦情など, 異常時は災害と位置付け，平時は利用者の「訓練」，異 常時は「発揮」という観点でいつでも，どのような場合 でも最大限活用できることを目的として構成した(図-4).

\section{(2) 本システム概要}

本システムのトップページ画面を示したものが図-5 である。この画面より，リアルタイムに情報提供される さまざまな情報に関して，その状況の把握，検索が簡単 に行えることを実現するため，先に述べたように大きく 4 つに分類して情報を整理することとした（以下の数字 は画面内の数字と対応している）.

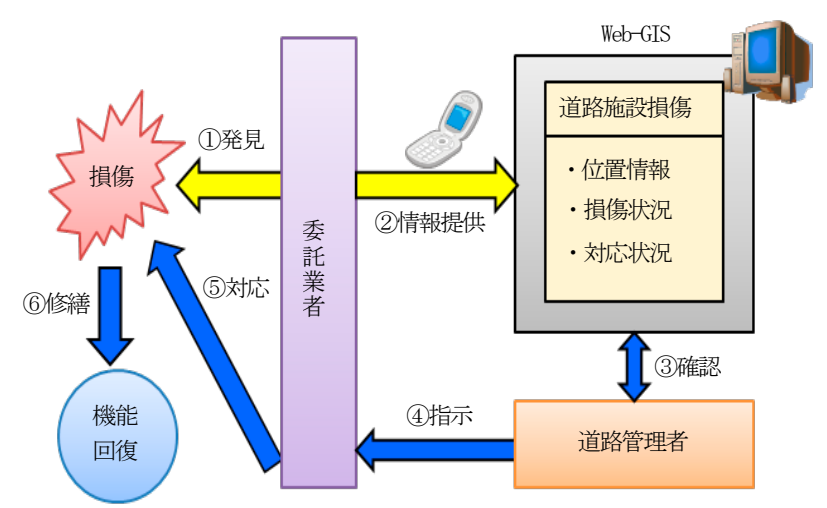

図-3 システムの流れ

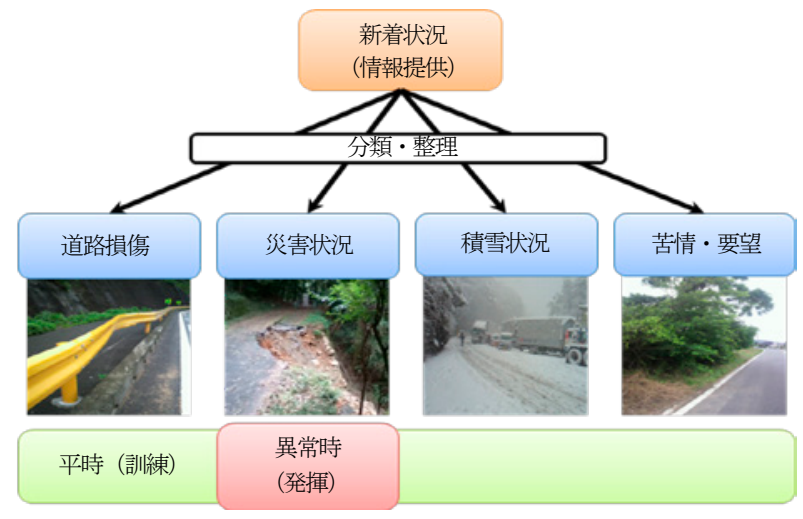

図-4 システムの構成

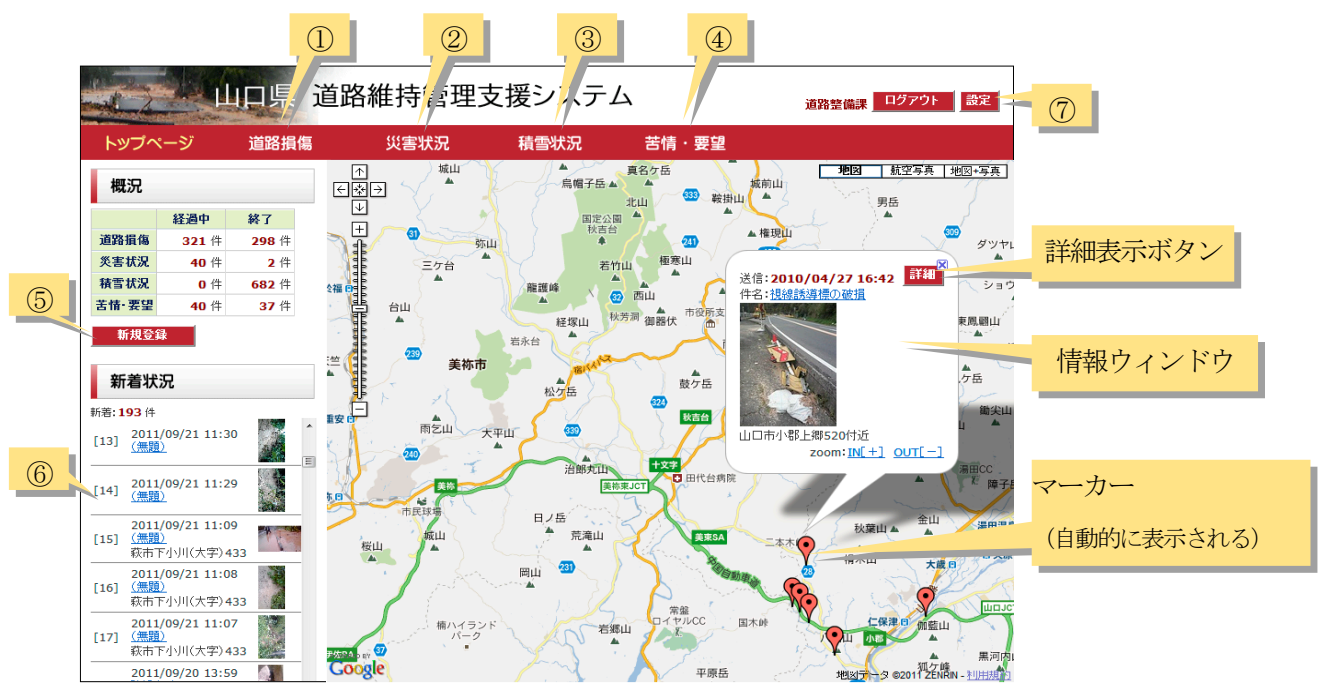

図-5 本システムのトップページ画面 
(1)道路損傷 : 通常パトロールなどによる道路舗装面な どの損傷状況.

(2)災害状況 : 大雨, 台風等により発生した道路災害の 状況.

(3)積雪状況 : 冬期における積雪，路面状況の情報. ※各土木管内において，事故発生が多い箇所，除雪の

目安となる箇所などの定点観測地点を選定し，パ

トロールを行う業者にその地点での情報を提供し てもらう。

(4)苦情・要望 : 地元などより受けた苦情，要望の情報. その他，以下の機能をトップページ画面内に配置した。

(5)新規登録 : 事務所で情報を新規登録することができ る.

（現場でデジタルカメラ等を用いて撮影した情報を 事務所に戻ってから登録することが可能）

(6)新着状況 : GPS 携帯電話で提供された情報がリアル タイムに表示される.

(7)設定 : 登録許可アドレスの設定を行う.

\section{a） 位置情報の付加}

道路施設損傷，災害などの現場からの情報提供につい
ては，道路損傷個所をGPS携帯電話で撮影を行い，位置 情報を画像に付加し，これを所定のサーバへ送信する (図-6参照)。このように，サーバへ新たな情報提供が あると，Web-GIS上にマーカーが自動的に表示され，同 時に道路損傷などの状況も情報ウィンドウ(図-5参照) により表示されるように工夫を施した.

\section{b) 詳細画面}

情報ウィンドウ内にある「詳細」ボタン(図-5 参照) を押すと詳細画面が表示される(図-7 参照) 。通常のメ 一ル作成時と同様に，件名や本文（コメント）に情報を 入力し送信すれば自動的に内容が盛り込まれ表示される. また，情報の修正や削除も行える.

\section{（3） 本システム内の各種機能概要}

\section{a) 修正および確認画面}

本システムでは，情報提供された内容に対し，修正， 追加することができる，すなわち，図-7 に示す詳細画 面内にある「修正する」ボタンをクリックすると修正画 面が表示される（図-8 参照）。ここで，修正および確 認項目の内容をまとめると以下のようになる.

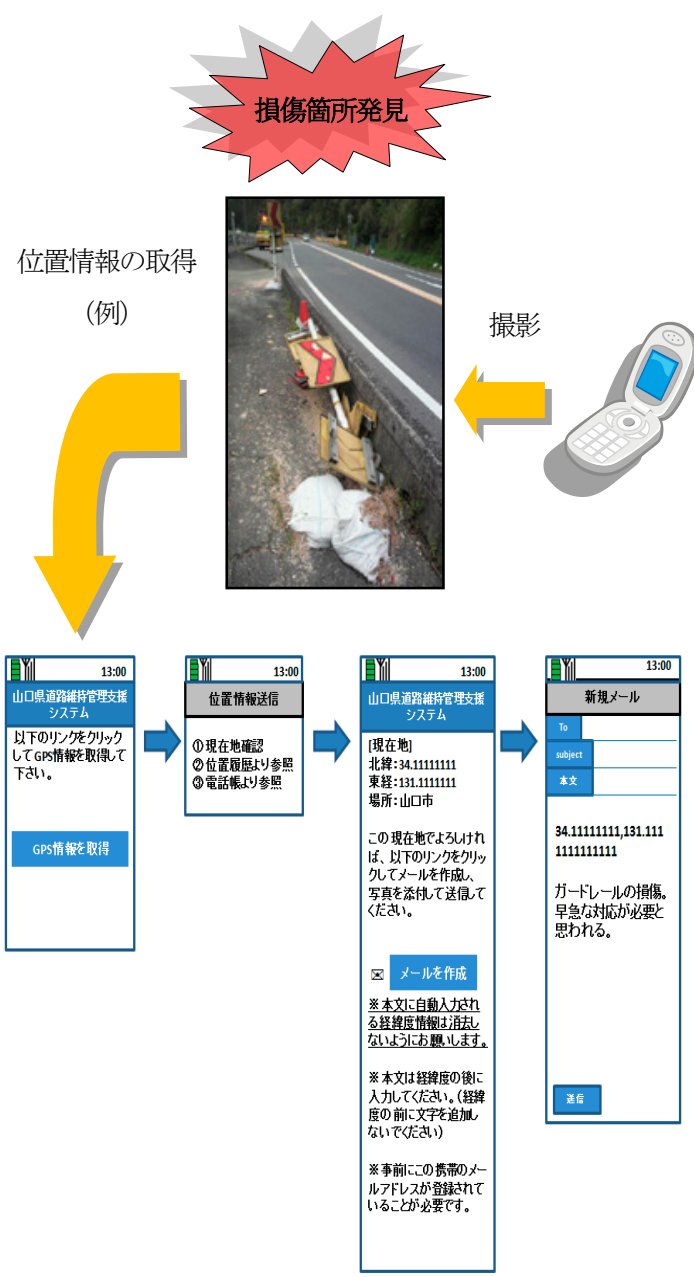

図-6 位置情報の付加

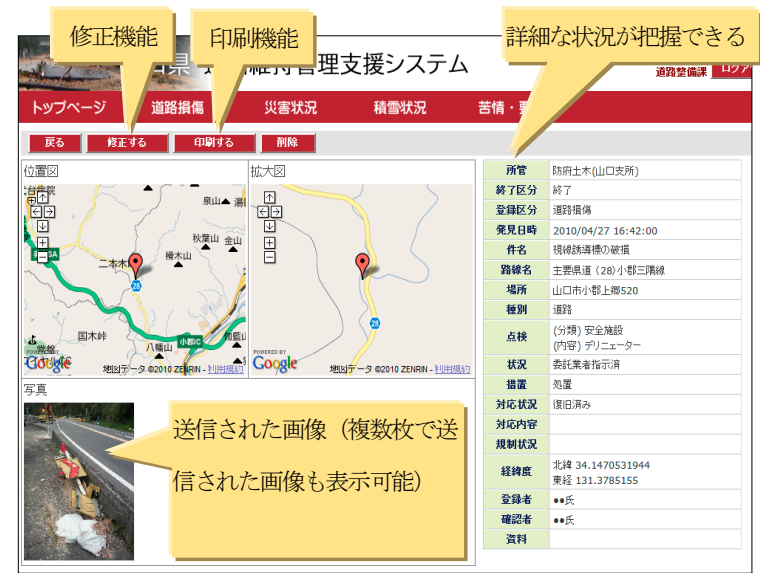

図-7 詳細画面

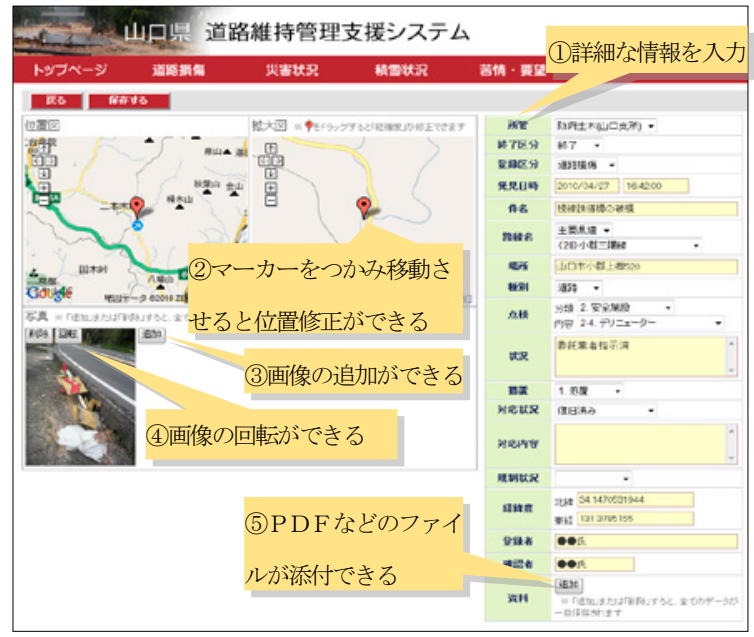

図-8 修正画面 
(1)詳細情報の入力と確認が行える.

(2)位置修正が必要となる場合は，「拡大図」に表示さ れているマーカーをマウスを使用してつかみ移動 させることで位置修正が行える.

(3)写真を追加する場合は，「追加」ボタンを押し，ア ップロードにより画像が追加添付できる.

(4)携帯電話を横向きや縦向きで撮影された画像に対し, 画像を回転させ向きを修正することができる.

(5)道路台帳等のPDFデータを追加したい場合は，項 目にある資料の「追加」ボタンを押し，アップロ ードにより追加添付することができる.

\section{b) 一覧表および検索表示画面}

本システムでは，前述図-7 の詳細画面の内容を一覧 表に切り替えることによって，今までに蓄積された情報 や経過内容などを適時確認寸ることができる機能を追加 している. この機能には図-9 に示すように, 以下の項 目が用意されている：

(1) データ検索画面 : 登録データの検索が可能で, 情 報提供された案件の状態が素早く確認できる.

(2) 一覧表画面 : 図-9 上側に示寸地図表示と図-9 下側 に示す一覧表表示の切替えが随時行える.
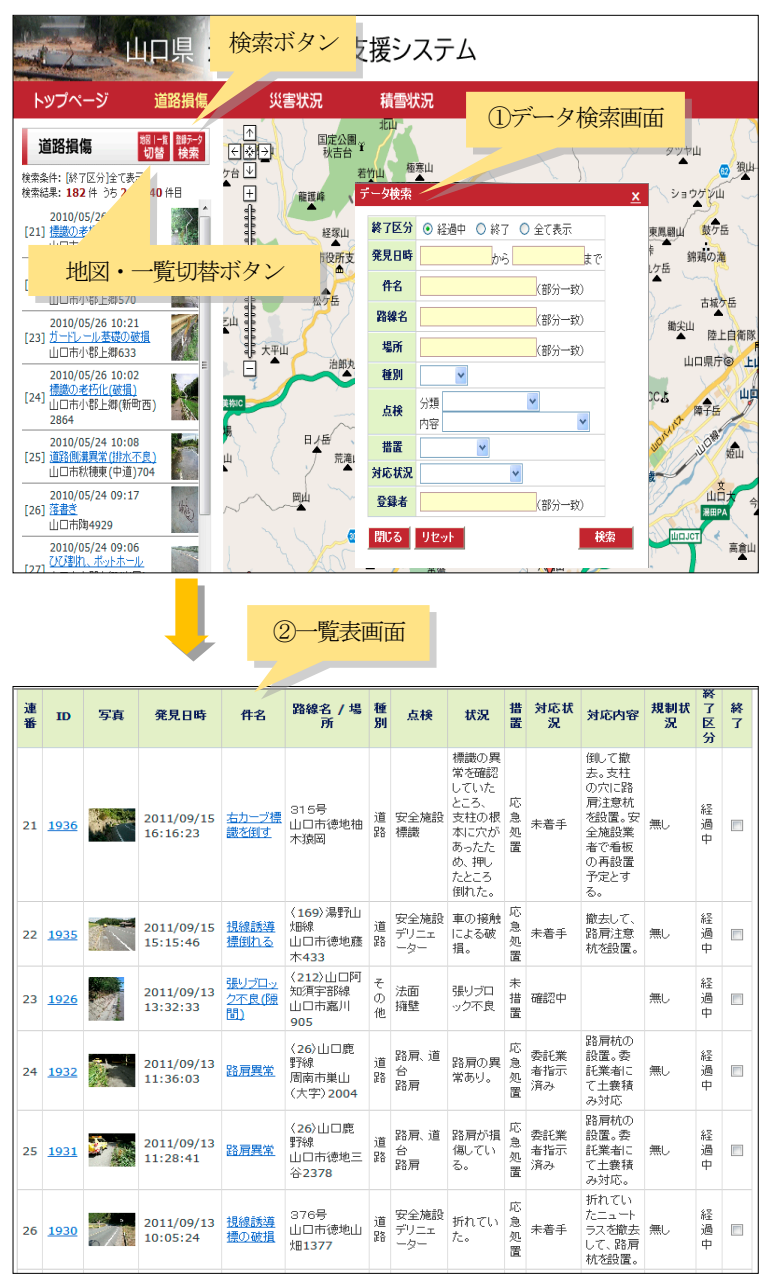

図-9 一覧表表示画面の例

\section{GPS 携帯電話による情報提供の課題}

\section{（1） GPS携帯電話情報による位置精度}

GPS 信号は, 上空約 2 万 $\mathrm{km}$ 伝搬して到達するため, 衛星の時計, 軌道誤差, 電波の伝搬に関連する誤差など で誤差を生じる．都市部などの市街地ではビル等により， 衛星からの電波が直接受信機に届かず，建物面に反射し た電波を受信してしまうことがあり，これによって実際 とは異なる位置を表示してしまうことがある。 また，山 間部など上空の見通しの悪い場合では，同時に捕捉でき る衛星の数が極端に減少し, 衛星の配置が偏るなどの影 響によって，位置情報の精度が大幅に低下寸る，その結 果，図-10 および図-11 に測定誤差の例およびその分布 例をそれぞれ示すように，実際に撮影した場所と WebGIS 上に示寸位置が異なる場合が生じる. すなわち, 図 -10 は，実際の撮影場所と GPS 携帯電話情報（観測 2 回 分）に基づく当該位置の誤差を具体的に示したものであ る. また，図-11 は，このような位置測定の誤差分布を $\mathrm{X}$ - Y座標上にプロットしたものである.これより， GPS 携帯電話情報に基づく位置測定にはかなりの誤差が 含まれる場合があることを認識しておく必要がある.

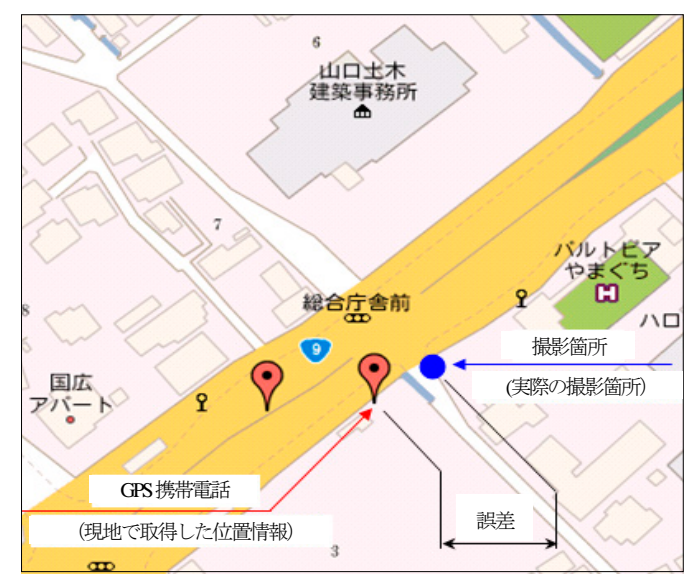

図-10 測位誤差の例

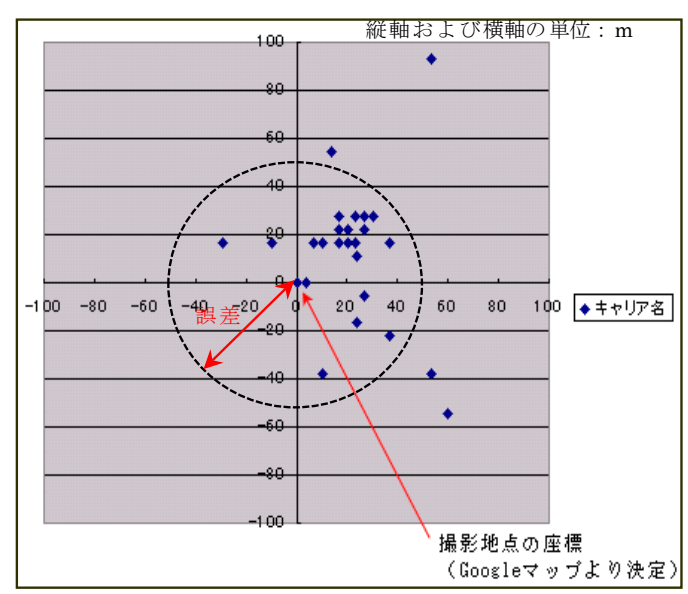

図-11 誤差の分布例 


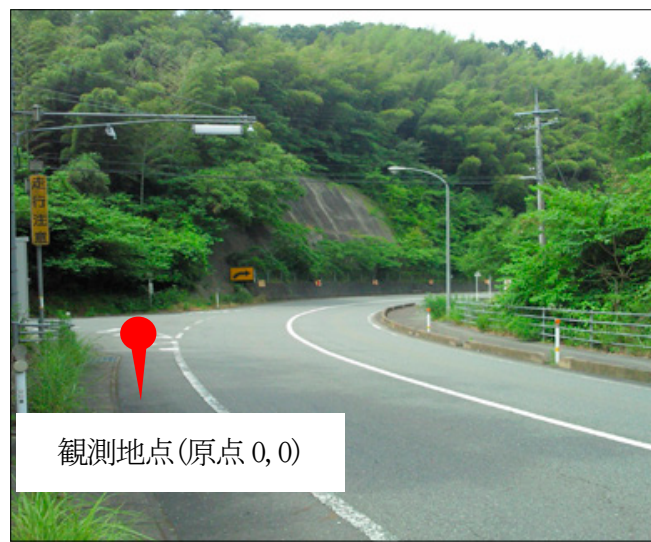

写真-1 山間部(観測地点)

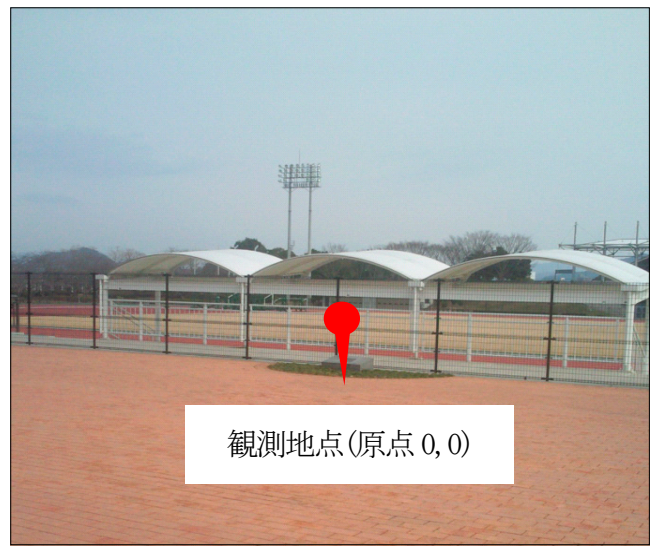

写真-2 市街地(観測地点)

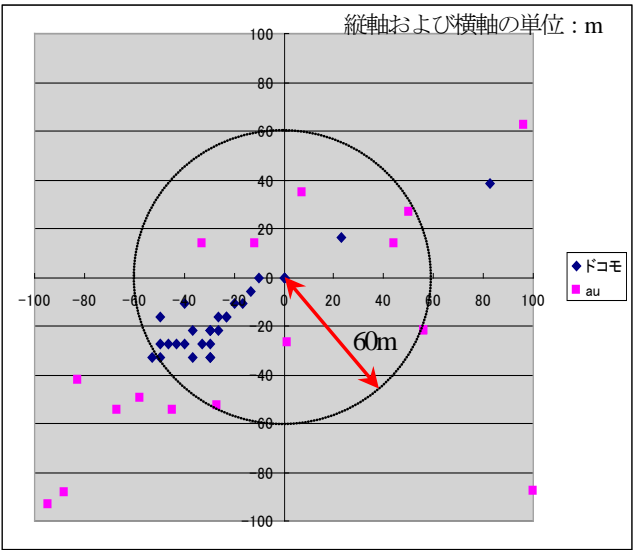

図-12 山間部(誤差)

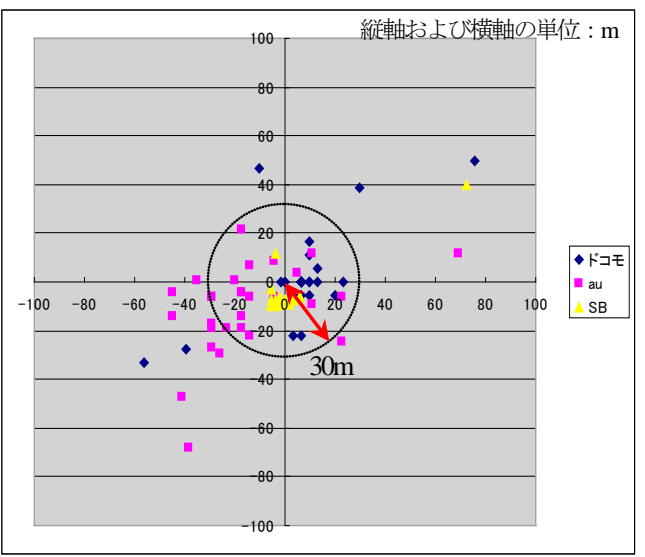

図-13 市街地(誤差)

経度 $131^{\circ} 26^{\prime} 20.4^{\prime \prime}$ 変換 $\rightarrow \mathrm{Y}=-39126 \mathrm{~m}$

\section{【携帯電話で取得した座標】}

緯度 $34^{\circ} 9^{\prime} 25.6^{\prime \prime}$ 変換 $\rightarrow \mathrm{X}=-191856 \mathrm{~m}$

経度 $131^{\circ} 26^{\prime} 20$. $0^{\prime \prime}$ 位置情報を 1 キャリア当たり 30 個のデータを取得して 精度に関する情報の収集を行った。また，緯度・経度情 報では，直感的な距離の違いが解らないため，これを平 面直角座標へ変換することにより, 距離感を数值として 把握できるようにした。今回は「XY B L T O O L 」 11) というフリーソフトを使用してデータ変換を行った. なお，撮影地点の座標は，あらかじめ Google マップよ り座標を取得し，それを原点として定め，携帯電話で取 得した座標と原点座標との差距離を，一例として図-11 に示すような誤差の分布図として表した。例えば，原点 座標を Google マップで取得した座標は, 以下にようにな る :

\section{【原点座標】}

$$
\begin{aligned}
\text { 緯度 } \quad 34^{\circ} \quad 9^{\prime} \quad 26.1^{\prime \prime} & \\
& \text { 変換 } \rightarrow \quad X=-191817 \quad \mathrm{~m}
\end{aligned}
$$

$$
\begin{aligned}
\text { 変換 } \rightarrow & Y=-39154 \quad \mathrm{~m} \\
(\mathrm{X}, \mathrm{Y}) & - \text { 取得座標 }(\mathrm{X}, \mathrm{Y}) \\
& =\text { 䛊差座標 }(\mathrm{X}, \mathrm{Y}) \mathrm{m}
\end{aligned}
$$

以上，位置情報の精度を確認した結果，キャリアによ って異なるが山間部で約 60m(図-12 参照:SB は測定不 能), 市街地で約 30m (図-13 参照)の誤差を生じているこ とが確認できた。 したがって，Web-GIS 上の位置情報に はある程度の誤差が生じ，また現場状況によっては大幅 に精度が悪い場合もあることから，情報を受け取る側は， 位置情報に注意し対応することが必要である.

\section{(2) 有効画素数の検討}

現在，ほとんど全ての携帯電話にはカメラが標準装備 となっており，その性能は，年々アップしている．発売 当初は 11 万画素数であったが，今では 1,000 万画素数を 
超える携帯電話も発売されてきている. しかし，画素数 が大きければ，視覚的に見栄えは良く，印刷を行った際 でも画像の粗さは目立たないが，一方，データ量が大き くなり, これに伴う送信時間と通信費を要してしまい, 処理するサーバへの負担も大きくなる，そこで，道路維 持管理上必要と思われる画素数について, データ容量と 送信時間及び通信費の相関を検証し，また画質について も最適な有効画素数を視覚的に検証し, 必要最小限の情 報提供ができることを確認した。

\section{a) 画素数、送信時間および通信費との関係}

各画素数のデータ容量, 送信時間および通信に伴う料 金を算出した。携帯電話料金には基本料金，通話料金お よびパケット通信料金とあるが，今回はパケット通信料 金のみで比較を行っている. パケット通信料金は, W e $\mathrm{b}$ サイトやメール，情報サービスなどを利用した時にデ 一夕通信にかかる料金で $1 \mathrm{~KB}=8$ パケットとなってい る. 1 パケット当たりの料金は, 携帯電話会社や料金プ

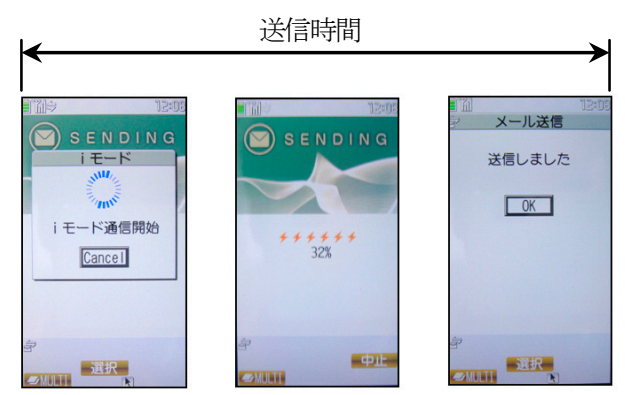

図-14 携帯電話の送信時間

表-3 データ容量と送信時間の比較一覧表

\begin{tabular}{|c|c|c|c|c|c|c|c|}
\hline \multicolumn{5}{|c|}{ 画素数 } & $\begin{array}{c}\text { データ容量 } \\
\text { (KB) }\end{array}$ & $\begin{array}{c}\text { 送信時間 } \\
\text { (秒) }\end{array}$ & $\begin{array}{l}\text { 費用 } \\
\text { (円) }\end{array}$ \\
\hline 1,536 & $x$ & 2,048 & $=$ & $3,145,728$ & 552.4 & 31.4 & 928 \\
\hline 1,080 & $x$ & 1,920 & $=$ & $2,073,600$ & 351.4 & 23.6 & 590 \\
\hline 1,212 & $x$ & $1,616=$ & $\bar{I}$ & $1,958,592$ & 347.4 & 17.3 & 584 \\
\hline 1,280 & $x$ & 960 & $=$ & $1,228,800$ & 170.2 & 15.4 & 286 \\
\hline 480 & $x$ & 854 & $=$ & 409,920 & 70.8 & 7.3 & 119 \\
\hline 640 & $\bar{x}$ & 480 & $=$ & 307,200 & 52.2 & 7 & 88 \\
\hline
\end{tabular}

※枚の画像索送信した場合を示寸。

※データ容量, 送信時間は, 5 回の平均值ししている。

※1280×960は， a㛧用いた情報でする。

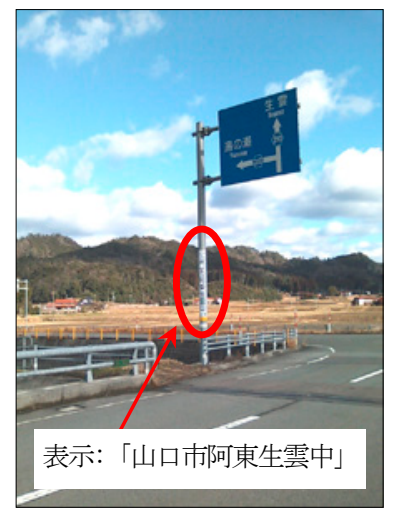

写真-3 道路標識全体写真
ランによって異なるがドコモの「F OMA」でO. 21 円となっており，今回はこれに基づき料金を算出した. 送信時間は，送信ボタンを押した時間から送信完了画面 が出てくるまでの時間を，図-14に示すように計測した. その結果をまとめて表-3 に示す。ここで, 鮮明な画像 はデータ容量が大きいため, 時間と費用が掛かることが 分かり，これが同時多発的に情報提供された場合，処理 するサーバの負担を大きくすることが懸念される.

\section{b) 有効画素数}

カメラ付き携帯電話で撮影した画像がどの程度の表示 サイズまで視覚的に道路維持管理上, 必要な有効画素数 であるのか検証した，比較方法は，道路標識（写真-3 参照）に記入されている「山口市阿東生雲中」部分のみ を切り出し, 約 120 万画素数 $(1280 \times 960)$ を原寸画像に設 定し，画素数毎にその文字の大きさまで拡大した場合で, 画像の粗さを視覚的に比較した（写真-4(1)〜(6)参照).

ここで「山口市阿東生雲中」の文字を写真-4のよう
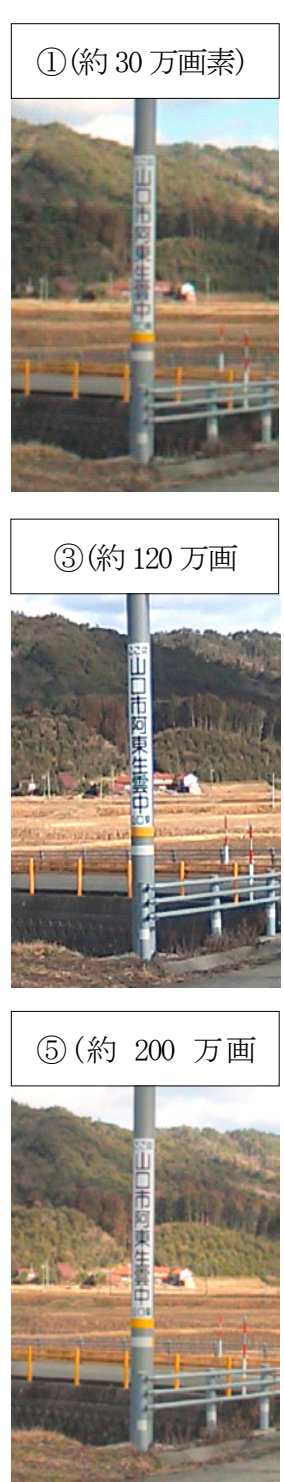

写真-4 原寸画像に対する文字画像の粗さ比較
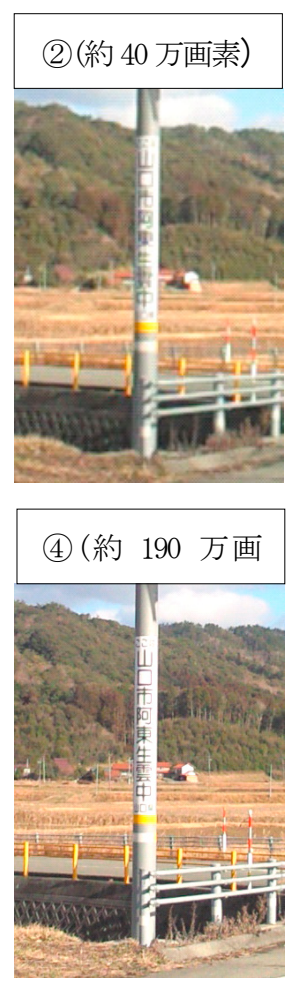

(6) (約 310 万画

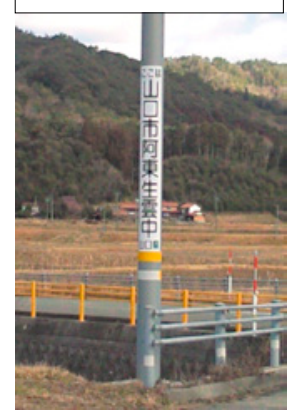


に「(3) $1280 \times 960$ (約 120 万画素数)」を原寸画像とし, 写真-4(1)，(2)は拡大，写真-4(4)，(5)，6は縮小としたも のでそれぞれ比較した. この結果, 約 120 万画素数以上 では鮮明度に差異がないため, それ以上の画素数での撮 影は必要ない。またそれ以下であっても，位置とある程 度の損傷状況が確認できれば，初動対応を迅速に行う上 で特に問題はない.

\section{（3）圏外における情報提供の対応}

GPS 携帯電話による位置情報取得については，GPS の 初期化，および基線解析の計算を基地局で行うため，電 波が届かないところ，いわゆる圈外では位置情報の取得 は不可能である. そこで, 現在のカメラ付き携帯電話の 機能にあるバーコードリーダー (バーコード読み取り装 置）を活用し，QR（クイックレスポンス）コードを用 いて位置情報の取得方法を検討した。 あらかじめ, GPS 受信機で取得した位置情報もしくは地図上により求めた 位置情報を QR コード化し，それを道路附属物（例えば， 標識, カーブミラーなど）に貼り付ける. 写真撮影後, バーコードリーダーによって，QR コードを読み取り位 置情報を取得して所定のサ一バへ送信する.しかし，そ の地点は圈外であることから，送信する場合は圈内へ移 動し情報提供することとなる．以下に， QR コードの概 要とその作成および活用方法について示す.

\section{a) QRコードの概要}

バーコードが普及し，その便利さが広く認識されるに 伴い，「より多くの情報を収納できるコード」「より多 くの文字種を表現できるコード」「より小さなスペース
で印字」「情報を暗号化したい」等々のニーズが高まっ てきた. そのため, 情報量を多くするためにバーコード の桁数を増やしたり，複数のバーコードを並べたりいろ いろな工夫も施されてきたが，一方で表示面積を大きく したり，読み取り操作を煩雑にしたり，印刷コストを上 昇させたりなど問題も見られるようになってきた. こう した中でニーズや問題に応えるため， 2 次元バーコード が出現した，その一種である QR コードは，「リーダー にとって読み取り易いコード」を主眼に 1994 年に「デ ンソーウェーブ(開発当時は侏)デンソーの一部門であっ た)」によって開発された.

$\mathrm{QR}$ コードは，当初の一方向だけに情報を持つバーコ 一ドとは異なり，縦，横二方向に情報を持つことで，記 録できる情報量を飛躍的に増加させたコードである，現 在では，搭載された QR コードのバーコードリーダーの ソフトウェアであるカメラ付き携帯電話の爆発的な普及 により情報の入出力やモバイルコンテンツ販売における 重要なツールとして用途が広がっている.

\section{b) QRコードの作成}

$\mathrm{QR}$ コードの作成は，ネット上で作成できるものもあ ればフリーソフトをダウンロードして作成できるものも あり，ごく簡単に作成することができる.今回は， 「psytec QR Code Editor」 ${ }^{12)}$ というフリーソフトにより, $\mathrm{QR}$ コードを作成し 道路施設に貼り付けた(図-15, 写真 -5 参照).

\section{c)QRコードの活用（位置情報の取得）}

山口市阿東管内にある「一般県道迫田篠目停車場線」 で一部圈外区間がある。当該区間はある程度標高があり，

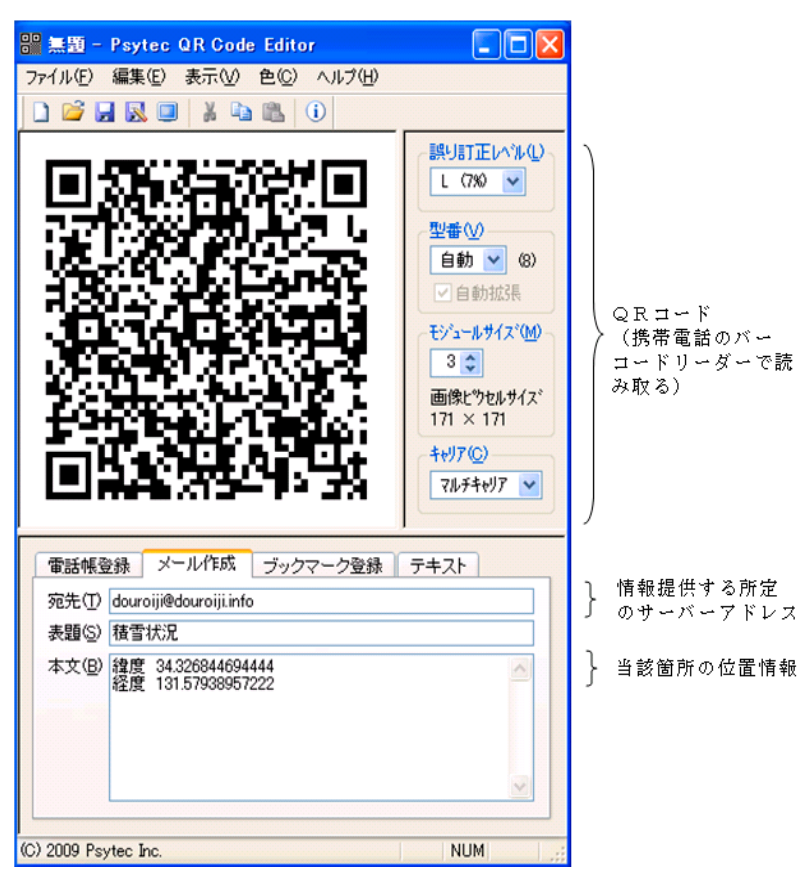

図-15 QR コードの作成

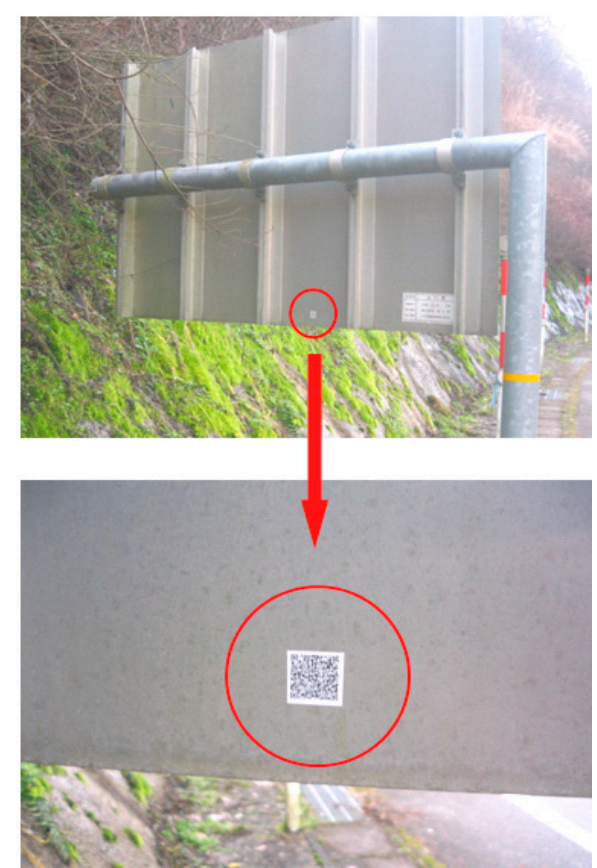

写真-5 QR コードの貼付 
縦断勾配も $6 \%$ 程度で急カーブ，S 字カーブが混在する 区間で，冬期では積雪も多く山間部であることから雪も 融けにくく凍結も頻繁に起こる箇所である. 軽度である が事故の発生も見られ，積雪情報を提供する必要な区間 である。この区間において，QR コードを活用した情報 提供の方法を以下に示寸(図-16参照)：【手順】

(1)携帯電話のバーコードリーダーを使用し，QR コ ードを読み取る。

(2)読み取り画面より，メールを作成して送信する.

(3)システムにアクセスし画面より, 修正画面でコメ ント欄にある座標で位置修正する。

\section{(4) 考察}

今回調査した山間部地域において，誤差の分布は密集 しているものの，実際の撮影地点に対し約 $60 \mathrm{~m}$ 程度の 比較的大きな誤差を生じていた。 これは，山間部に連な る山々が障害となり, 電波を同時に補足できる衛星の数 が減少するためなどが原因となっている，一方，市街地 においては, 上空に障害がないことから，山間部地域に 比べて比較的に精度の良い結果が得られた. 本システム では，位置情報だけでなく現場状況の画像も同時に提供 されるので, 精度が悪くても周辺状況などが画像により 確認できるため，おおよその位置は把握できる．なお， 山間部地域ではソフトバンク社製携帯電話のみが，圈内 となる範囲が他より狭かったためデータ数としては十分 な量を取得できなかった. 次に, 有効画素数の検討結果 については，画素数，送信時間および通信費との関係
により, データ容量が大きいほど送信時間が長く, コス トも掛かる結果となった。これを画質との関係で考える と, 文字を明確に把握できる画素数範囲として, 約 120 万画素数以上ではそれほど視覚的に差はなく, どこまで の拡大が必要なのか現場状況によって異なるが，山口県 が行う維持管理業務に関しては, 約 120 画素数以上は必 要ないと思われ，通信費のことを考えればそれ以下でも 問題はない. このように維持管理業務で必要となる画素 数については, 今後いろいろな携帯電話により提供され る画像から最適画素数を検討寸る必要がある.

最後に，圈外における情報提供については，QR コー ドを用いることによって位置情報を取得できることが分 かった．だが，情報発信するためには圈内一移動しなけ ればならないため, 通常の情報提供に比べ, リアルタイ

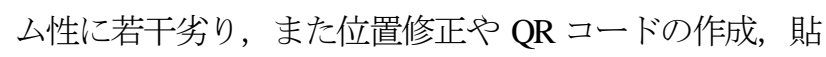
付などの手間も生じてしまう。しかしながら，圈外とい う条件および GPS 携帯電話を利用する観点から，この

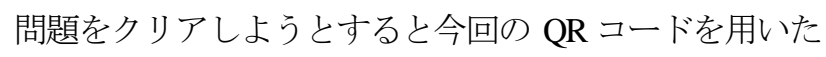
手法は，一つの有効な方法と言えることが分かる.

\section{6. 本システムの適用例}

\section{（1） 道路施設損傷の情報提供}

一例として，写真-6に示すような位置情報と道路施設 の損傷状況が提供されるため, 電話確認の際に前述の 「山口県の道路施設維持管理業務フロー」（図-1左側
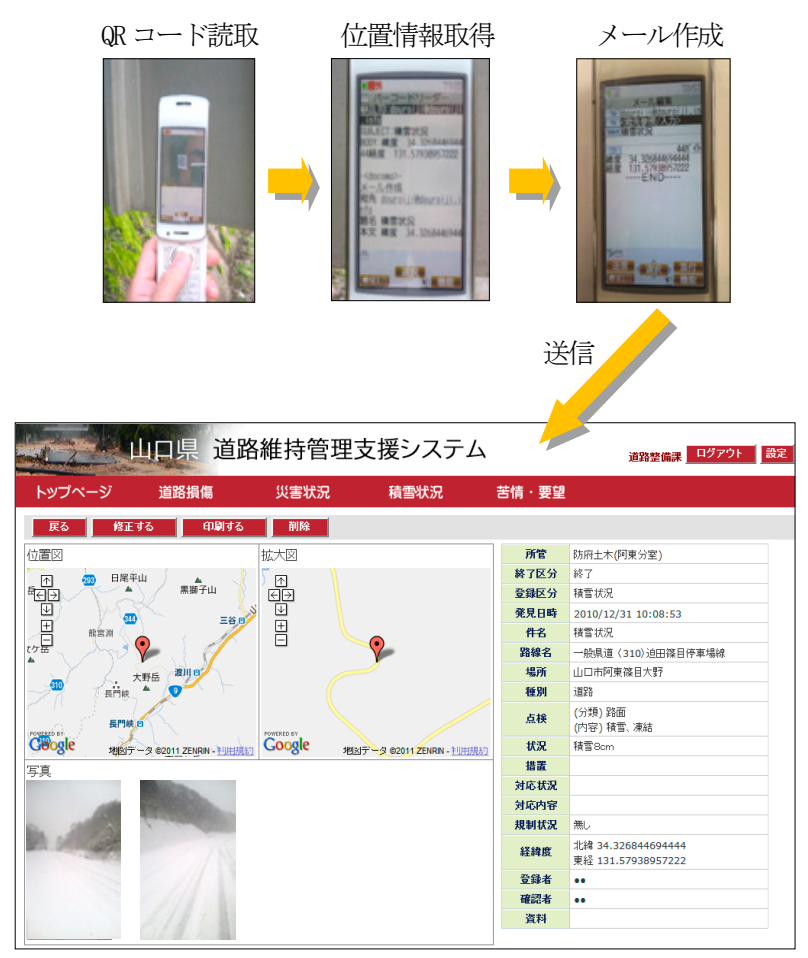

図-16 QR コードを活用した情報提供の例
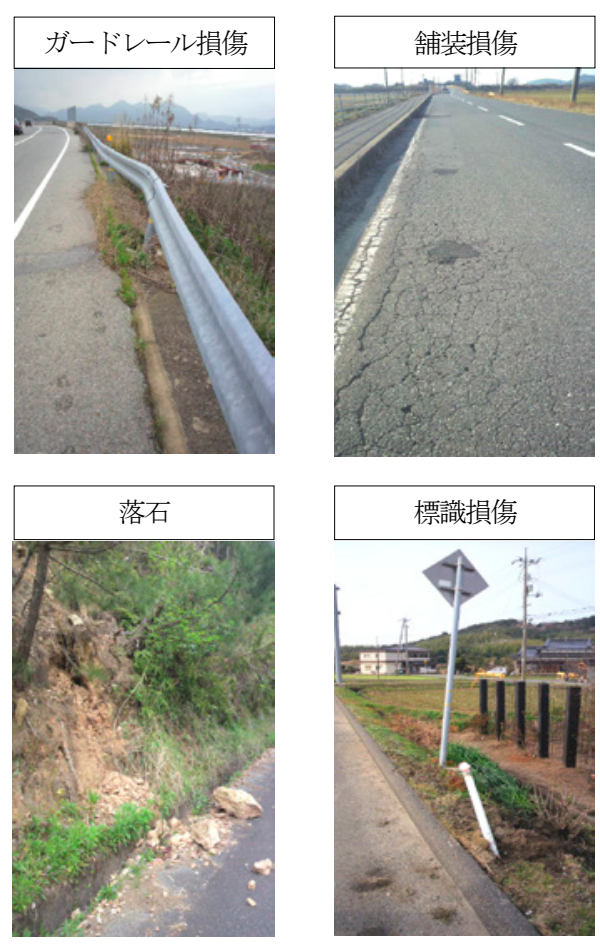

写真-6 道路施設の損傷状況例 
参照）で示したステップ2.の位置特定のやり取りが不要 となり，素早くどのような対応を行うのか委託業者入指 示を出すことができる. それに伴い委託業者も迅速に対 応し, 安全性の確保がより早く図ることができた。

また，昨年 2010(H22)年 7 月中旬の集中豪雨により， 道路法面が崩壊して土砂が道路を塞いだ道路災害の情報 も提供された（写真-7 参照）。このような情報により， 発生位置，災害規模，交通規制，復旧方針など一連の作 業が効率的に行われ，また情報の共有化が図られたため， 迅速な対応が可能となり，被災後，翌日には交通解放 （仮復旧）することができた（写真-8 参照）。

\section{（2）冬期路面の情報提供}

冬期における積雪や路面状況の情報提供については, 事故発生確率の高い個所などに絞り込み，情報提供を行 った．現在，山口県では，9個の定点カメラが設置され ており，期間限定で道路利用者に対し積雪状況を提供し ている（通称：山口県道路情報 道路見えるナビ）。今 回，GPS 携帯電話を用いた情報提供は，これと比べてリ アルタイム性には少し劣る. しかしながら，定点カメラ

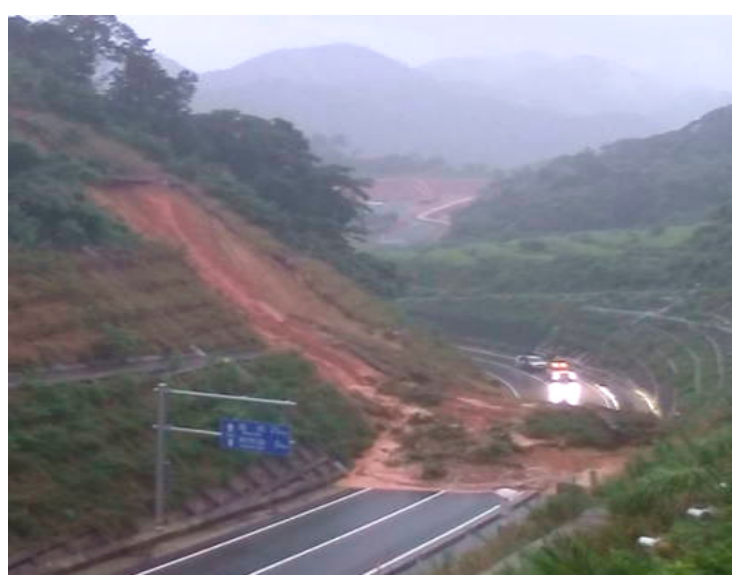

写真-7 被災直後

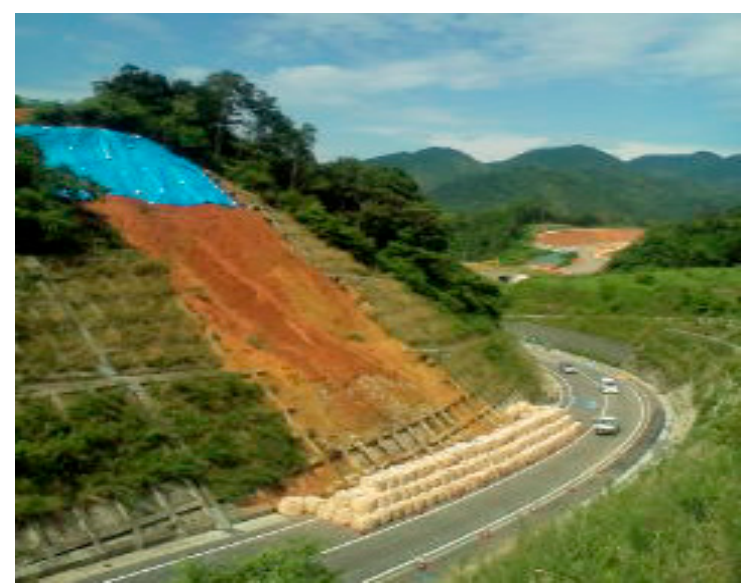

写真-8 仮復旧後
以外の情報として, 路面状況（写真-9 参照）の補足情 報により除雪作業のルート検討などの情報として有効な ものであった．また，事故発生箇所や大雪に伴う車両渋 滞箇所 (写真-10 参照) の位置と現場状況がリアルタイ ムに把握できたので，通行止め区間や迂回路選定などの 検討に役立てることができた.

\section{7. システムの評価と導入効果}

\section{(1) システムの評価}

GPS 携帯電話を使用することにより，位置情報取得と 画像送付などの作業が追加されることになるが，その後 のステップでの位置確認や報告書作成および委託業者へ の依頼など，本システムによって様々に異なる作業が一 元化されることとなる. これより，前述 3.の図-1 に 示した現状の「山口県の道路施設維持管理業務つロ 一」に比べて情報通信技術（ITC）を積極的に取り入 れることによって，リアルタイムで各種データの効率的 な共有化を可能としたと言える．以上により本システム

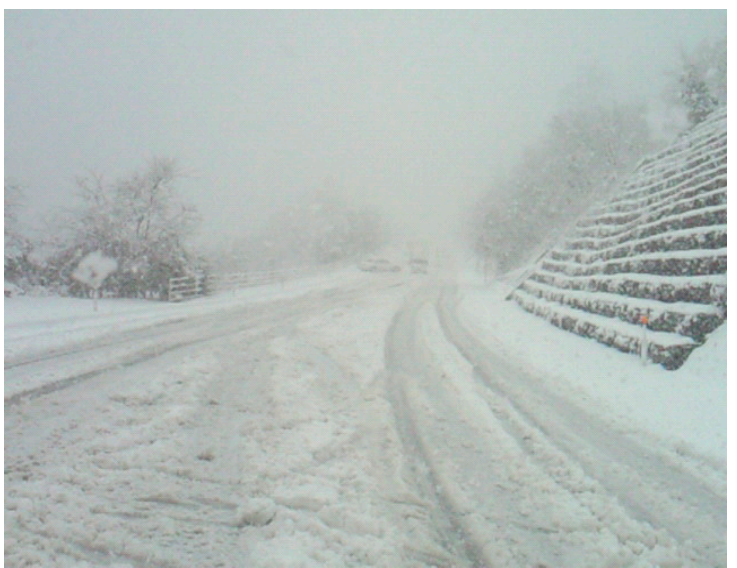

写真-9 積雪の路面状況例

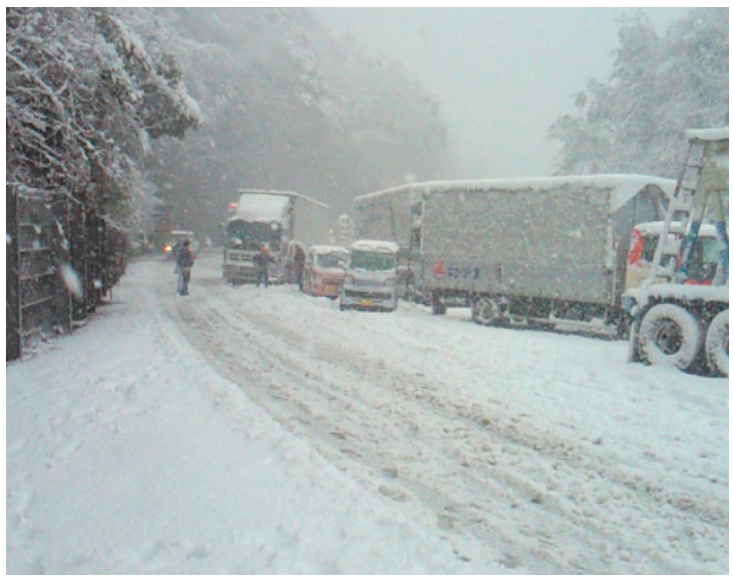

写真-10 積雪による車両の渋滞例 


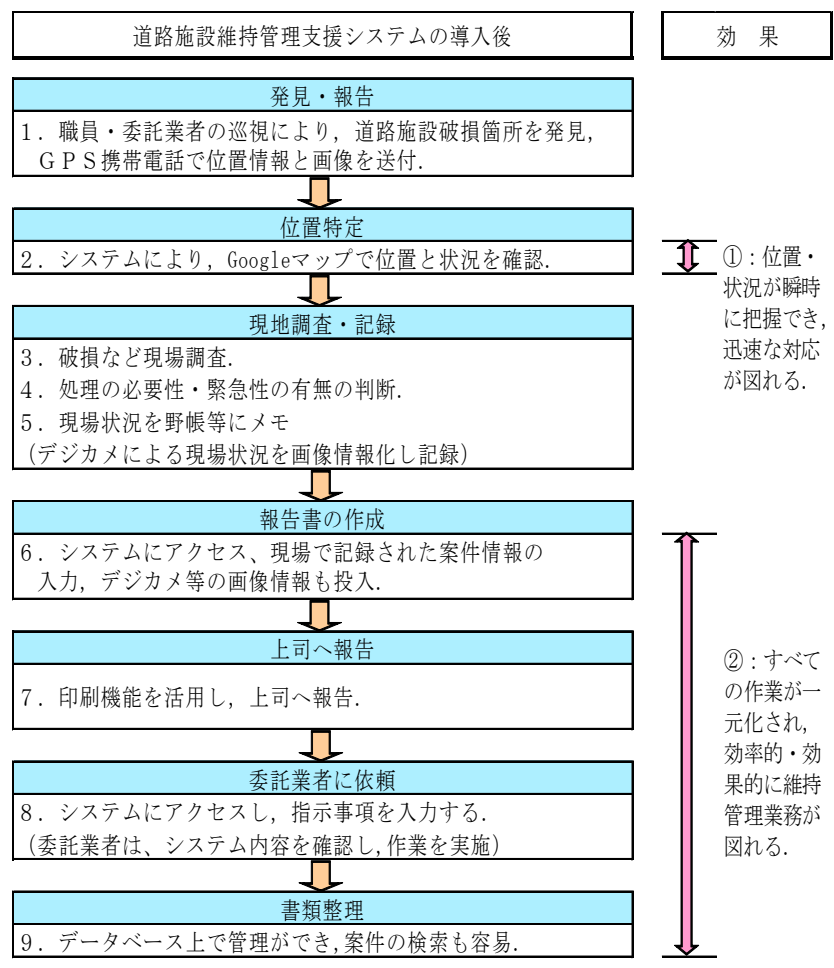

図-17 導入後の道路施設維持管理業務フロー

を導入した後の道路施設維持管理業務フローを図-1 左 側のステップと対応させて示すと，図-17のようになる.

\section{(2) 導入効果}

現場から位置情報と案件の画像がリアルタイムに把握 できるので，上司への報告と委託業者に対する指示が迅 速に行える効果がある. また, 事前に状況を把握するこ とができるため，重要案件の場合では，事務所内で事前 協議を行い，あらかじめ方針を確認した上で現場が確認 できるため, 適切な判断と指示が行える. もちろん, 情 報の共有化が図られるため, 担当者不在等の場合でも， 案件の処理状況，進捗状況がいつでも，どこでも，だれ でも確認することができる，また，データベースで管理 しているので, 過去の案件の検索が容易にできる. そし て, 事故の発生箇所, 落石が多く見られる箇所, 苦情が 頻繁している箇所などのデータが蓄積されることによっ て，これらの案件を予防保全的に対処する維持管理業務 も可能となると考えられる. 以上のような本システムの 導入効果をステップごとに特徵をまとめたものが表-4 である.

\section{（3）県職員および委託業者からの意見徵集}

本システムを活用した評価について，県職員および委 託業者に意見を聴取したので以下に要旨を示す.

【効果】：位置と画像が一度に把握でき，しかも，情報
表-4 導入効果の一覧

\begin{tabular}{|c|c|}
\hline $\begin{array}{c}\text { 項目 } \\
\text { (ステップ) }\end{array}$ & 導 入 効 果 \\
\hline 発見・報告 & $\begin{array}{l}\text { GPS携帯電話を使用し情報提供する手 } \\
\text { 間が追加されるが，後作業に対する効 } \\
\text { 率化が図られる. } \\
\end{array}$ \\
\hline 位置特定 & $\begin{array}{l}\text { 位置と状況がリアルタイムに把握で } \\
\text { き, 迅速な対応と判断が可能となる. }\end{array}$ \\
\hline 現地調査・記録 & $\begin{array}{l}\text { 現場から画像情報が提供されるので, } \\
\text { 入力作業の一部が簡素化される. }\end{array}$ \\
\hline 報告書の作成 & $\begin{array}{l}\text { 全ての作業の一元化が図られ, 報告書 } \\
\text { 作成等の効率性が向上する. }\end{array}$ \\
\hline 上司への報告 & 全ての作業の一元化が図られる. \\
\hline 委託業者に依頼 & $\begin{array}{l}\text { 正確・迅速・効率的に伝達が可能とな } \\
\text { る. }\end{array}$ \\
\hline 書類整理 & $\begin{array}{l}\text { 処理後の案件が容易に検索でき, 蓄積 } \\
\text { データの活用も行える. }\end{array}$ \\
\hline
\end{tabular}

がリアルタイムに確認できるため, 素早く業者に指示が 行え，損傷発見から補修まで効率的に対応できた。 また， 位置修正が簡単にできることや，携帯電話で撮影した画 像が縦横で逆に写し出された場合でも，写真を回転でき る機能があるので助かる，道路管理者に対し，位置説明 や現場の損傷度合も簡単に説明できるため，お互いの意 思疎通が確実に行えるので対応が早い.

【改善点】：GPS 携帯電話での位置情報取得及びメール の打ち込みが少々面倒である. 維持管理の専用アプリを 作成し, 携帯電話の操作性（写真撮影 $\rightarrow$ 位置情報取得 $\rightarrow$ メール作成）の向上を図ってほしい.

\section{8. 蓄積データの活用事例}

\section{(1) 蓄積データを活用した効率的な道路施設維持管理 の試案}

本システムを活用し，道路施設損傷および災害，また 住民からの苦情, 要望などさまざまな情報が提供され, その対応状況や道路施設損傷状況などのデー夕の蓄積が 行われる. 一方, それに伴うデータ量の増大や乱雑な取 り扱いなどが予想されるため, 適切なデータの整理整頓 が必要であり，また災害などの過去の大量の案件から業 務の補足情報を取得するなどデータを有効に活用するこ とが重要である ${ }^{13)}$. そこで，本システムにより蓄積され 
た大量のデータの整理および活用手法について 2 例を挙 げ提案する.

\section{a) 維持管理におけるハード対策例}

自動車事故によるガードレール破損箇所や落石箇所な どにおいて, 繰り返し発生した箇所の頻度を整理, 分析 を行う。マップ上の図-18 のように, 過去に発生したガ ードレール破損箇所群（集合体(1)）之落石箇所群（集合 体(2)）を「集合体」として地図上で確認することができ る.これに基づいて，検索システムを活用し，集合体の 内容を確認できる発生頻度の一覧表を作成する（表-5 参照）。それらの内容と発生原因を分析し, 繰り返し行 われる事故発生個所については，局部線形改良(図-19 参照)や安全施設の強化，また落石が多い個所について は，現地調查し落石防護柵などの設置（図-20 参照）を 行い，重大な事故に至る前に対症的措置として対策を講 じることができる ${ }^{14}$.

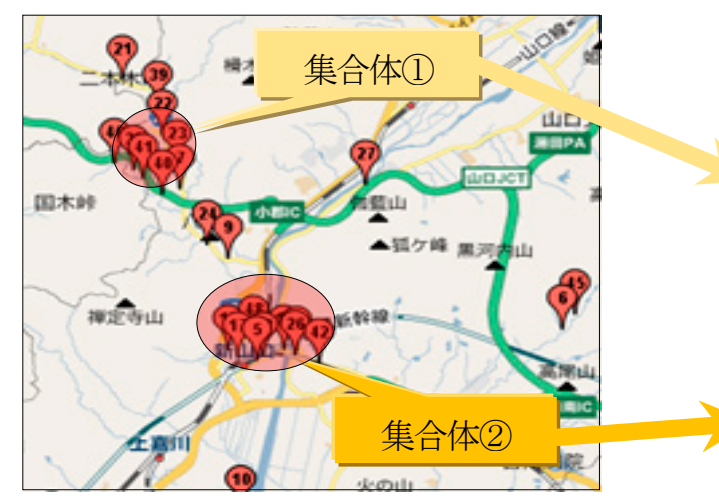

図-18 地図上での発生箇所の集合体(1)、(2)

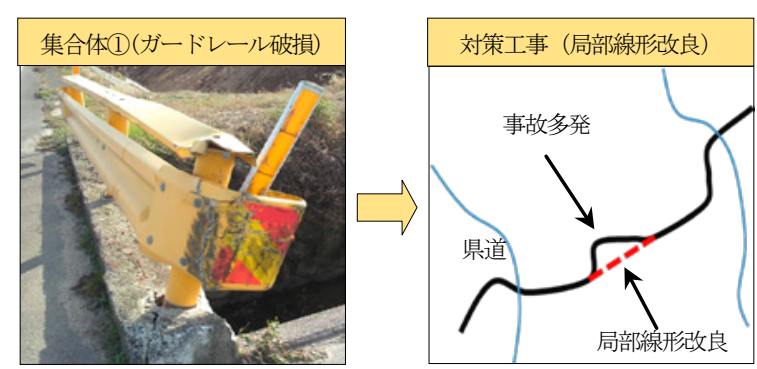

図-19 局部線形改良対策例

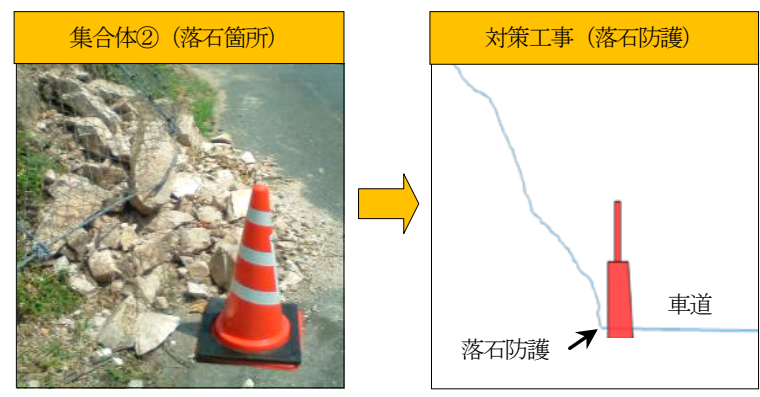

図-20 落石防護柵設置対策例

\section{b) 道路施設維持管理パトロールの効率化}

山口県内の道路は国道, 主要県道および一般県道ごと に路線が分けられ，各土木建築事務所の管内ごとに，維 持管理パトロールの計画を立て効率的に日常巡視が行わ れれている ${ }^{15)}$. 従来のパトロール計画を踏まえ, 蓄積 された損傷データを利用することにより，さらに効率的 かつ効果的に維持管理パトロールを行うことが可能とな る. 図-21 に, 道路損傷箇所から各路線における損傷頻 度を分析し，効率的な維持管理パトロールルートの再設 定を行う流れの検討手順を示す. 図-21 に示す事例では, マップ上で確認できる道路施設損傷箇所（図-21 の左上 参照）をデータ検索システムの活用によって蓄積された データを路線区間ごとに，道路損傷が発生している件数 を集計する（図-21 の右上一覧表参照）。この一覧表か ら, 各路線区間における損傷頻度が多い路線，すなわち 損傷発生危険度が高く, しかもヒヤリハットも含まれる
表-5 発生頻度一覧

\begin{tabular}{|c|c|c|c|c|c|c|}
\hline 路線名 & 市町名 & 場所 & 日時 & 損傷分類 & 集合体 & 対策工事 \\
\hline \multicolumn{7}{|l|}{ 主要県道 } \\
\hline \multirow{7}{*}{ 000線 } & \multirow{7}{*}{$\boldsymbol{\Delta} \boldsymbol{\Delta}$ 市 } & 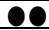 & $\mathrm{H} 21.8 .1$ & カーードレール & 1 & \multirow{7}{*}{$\begin{array}{c}\text { 局部 } \\
\text { 線形改良 }\end{array}$} \\
\hline & & 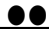 & H21.9.2 & ガードレール & 1 & \\
\hline & & 0 & H21.11. 15 & ガードレール & 1 & \\
\hline & & 00 & H21.12.15 & ガードレール & 1 & \\
\hline & & 0 & H21. 12.23 & ガードレール & 1 & \\
\hline & & 00 & H22. 1.25 & カ゚ードレール & 1 & \\
\hline & & 00 & H22.2.1 & カ゚ードレール & 1 & \\
\hline \multicolumn{7}{|l|}{ 一般県道 } \\
\hline \multirow{7}{*}{ DED線 } & \multirow{7}{*}{$\boldsymbol{\Delta} \boldsymbol{\square}$ 市 } & 00 & H21.6.3 & 落石 & 2 & \multirow{7}{*}{$\begin{array}{c}\text { 落石防護 } \\
\text { 柵設置 }\end{array}$} \\
\hline & & 00 & H21.9.2 & 落石 & 2 & \\
\hline & & 00 & H21.11.15 & 落石 & 2 & \\
\hline & & 00 & H21. 12. 10 & 落石 & 2 & \\
\hline & & 00 & H21. 12.18 & 落石 & 2 & \\
\hline & & 00 & $\mathrm{H} 22.1 .25$ & 落石 & 2 & \\
\hline & & 00 & H22.2.20 & 落石 & 2 & \\
\hline
\end{tabular}
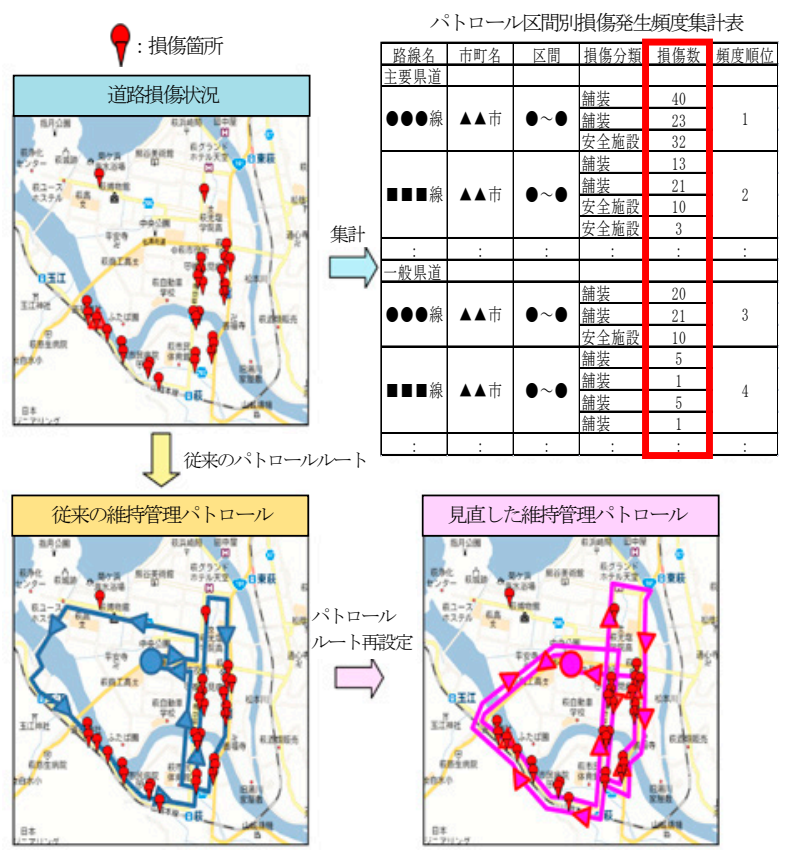

図-21 パトロールルート効率化の検討手順 
路線として位置付けられる.これにより, 従来の維持管 理パトロールルート（図-21 の左下参照）から，各路線 の頻度順位を参考に，パトロールルートや路線ごとのパ トロール頻度の検討に基づいて再設定する（図-21 の右 下参照）。これにより，効果的なパトロールの実施が行 われ，より安全・安心な道路利用の向上を図ることがで きる.

\section{9. まとめ}

本論文の結論は，次のようにまとまめることができ る :

(1)GPS 携帯電話の位置情報機能とWeb-GIS を活用した道 路施設維持管理支援システムの開発を行った.これによ り，位置情報と道路施設損傷状況がリアルタイムに把握 でき，迅速な対応と情報の共有化が図られ，効率的な維 持管理を行うことができ，より安全で安心な社会基盤の 構築を図ることができるものと考える.

(2)GPS 携帯電話における位置情報の誤差については, 検 証試験でおおよその誤差を確認することができ，それを 踏まえた情報確認が必要であることを認識した.

(3)携帯電話で撮影寸る有効画素数については, 鮮明な画 像ほどデータ容量が大きく, 通信費も高く, サーバへの 負担も大きいが，道路施設を維持管理する上では，状況 と規模がある程度判るものであれば，画素数が少なくて も特に問題はない.

(4)圈外区間の対応については，QR コードを用いた位置 情報の取得方法を紹介した，QR コードの作成，貼付の 手間は掛かるが，簡単に安く誰でもできること，また位 置情報の取得も GPS 携帯電話により容易にできることか ら，その有効性を確認できた。

(5)本システムにより蓄積されたデータを単に履歴として 残すのではなく, データを維持管理におけるハード対策 の検討や維持管理パトロールの効率化が図れるなど，各 対応における蓄積データを有効に活用した手法を提案し た．今後，運用を繰り返すことによって，さらにデータ 量が増大し乱䧱な取り扱いなどが予想されるため，適切 なデータの整理整頓が必要であり, これら大量のデータ を有効に活用できるシステム展開が必要である.すなわ ち，デー夕を対症療法（事後保全）的対応と予防保全的 対応に分類し，蓄積されたデータを有効に活用する道路 施設管理アセットマネジメントを展開する予定である.

謝辞 : このシステム構築及び試験運用にご協力頂いた山 口県旧山口土木建築事務所維持管理課職員並びに山口県 土木建築部道路整備課職員の皆様に感謝の意を表する.

\section{参考文献}

1）西村亘:災害から学ぶ〜防災文化と危機管理〜 2011.3.28

2）大堀勝正,森岡弘道,森地茂 : 道路維持体制の人員配分手法 と適用事例,土木学会論文 F, Vol.64, No.4,pp.381-393,2008.11

3） 大堀勝正,森地茂 : 道路維持における行政需要に応じた人 員配置の最適化手法, 土木学会論文集 F, Vol.66, No.3, pp.412$431,2010.8$

4）古畑貴志,吉澤憲治,小野孝司,寺田守正,吉田和正,矢野高一, 中村喜輝,佐野嘉紀,井上明,金田重郎，「Web-GIS を用いた 道路管理システム「京都道守くん」の開発」,情報処理学 会,第69回全国大会,3ZA-9,3月,2007年.

5）吉澤憲治,古畑貴志,小野孝司,寺田守正,吉田和正,矢野高一, 中村喜輝,佐野嘉紀,井上明,金田重郎，「Web-GIS を用いた 道路管理業務支援システム”京都道守くん”の開発」,情報 処理学会研究報告・2007-IS-99,pp.39-44,3月,2007年.

6) 位置コミ http:/www.ichi-comi.com: 2011.10現在

7）荒木孝彦：GPS 携帯による災害情報共有システムの構 築 : 建設マネジメント技術 2009年 9 月号

8）窪田論,小澤田貴泰,加藤誠,小田島直樹,阿部明博,岩手県立 大学ソフトウェア情報部,小田島 I T 事業部 : 道路維持管 理システムの長期運用によるデータの整理と分析, 情報処 理学会研究報告 2009-IS-107,pp71-76 2009.3

9）一瀬邦継,中西正樹,寺田守正,藤澤裕樹,吉澤憲治,金田重 郎：道路維持管理業務支援システムにおけるデータマイ ニングの適用,情報処理学会研究報 2009-IS-108,No.5,2009.6

10) Google マップホームページ

http://maps.google.com/maps: 2011.10 現在

11) XYBL TOOL ホームページ http://www.n-survey.com/xybl/index.htm:2011.10 現在

12) Psytec QR CodeEditor ホームページ http://www.psytec.co.jp/docomo.html : 2011.10 現在

13）蒔苗耕司：土木における情報の意義と役割，土木学会論 文集 F, Vol.64, No.2,pp148-162,2008.5

14）吉田武：道路構造物維持管理における対症的維持の意義 と改善, 土木学会論文集 F, Vol.66, No.1,pp.208-213,2010.3

15）貝戸清之,小林潔司,加藤俊昌,生田紀子 : 道路施設の巡回 頻度と障害物発生リスク，土木学会論文集 F, Vol.63,No.1, pp.16-34,2007.2

(2011.10.20) 


\section{DEVELOPMENT OF A REAL-TIME FORECASTING SYSTEM FOR ROAD FACILITIES IN YAMAGUCHI PREFECTURE AND ITS PRACTICAL APPLICATIONS}

\section{Satoru YAMANE, Takashi YOSHIMURA and Ayaho MIYAMOTO}

Maintenance strategy for road facilities on the road network which is an essential lifeline supporting our life is becoming a major social concern in safety and securer civil societies for not only Yamaguchi prefecture but also other prefectures in recently. This paper describes a road facilities maintenance management support system combined with the latest information and communication technologies, such as the information function at the position of the GPS cellular phone with web GIS, etc. By using the system, because information can be shared by using location information function, photograph function, e-mail functionality, and web GIS of the GPS cellular phone to its maximum, an efficient, effective maintenance management can be done. From the comparison of the results of applying the system to an actual road network in Yamaguchi prefecture area, the road administrator can in real time confirm the position and the situation of the facilities damage of the road from the Internet, and a quick mending can be done. 